\title{
Evolution of Holdfast Diversity and Attachment Strategies of Ediacaran Benthic Macroalgae
}

\author{
Xiaopeng Wang ${ }^{1,2}$, Mengyin Wu ${ }^{3}$, Bin Wan ${ }^{1,2 *}$, Changtai Niu ${ }^{1,4}$, Wentao Zheng ${ }^{1,2}$, \\ Chengguo Guan ${ }^{1}$, Ke Pang ${ }^{1,2}$, Zhe Chen ${ }^{1,2}$ and Xunlai Yuan ${ }^{1,2}$
}

${ }^{1}$ State Key Laboratory of Palaeobiology and Stratigraphy, Nanjing Institute of Geology and Palaeontology and Center for Excellence in Life and Paleoenvironment, Chinese Academy of Sciences, Nanjing, China, ${ }^{2}$ College of Earth and Planetary Sciences, University of Chinese Academy of Sciences, Beijing, China, ${ }^{3}$ School of Economics and Management, Guiyang University, Guiyang, China, ${ }^{4}$ School of Earth and Space Sciences, University of Science and Technology of China, Hefei, China

OPEN ACCESS

Edited by: Juliana Leme,

University of São Paulo, Brazil

Reviewed by: Manuel F. G. Weinkauf, Charles University, Czechia Natalia Bykova, Institute of Petroleum Geology and Geophysics (RAS), Russia Katie Maloney, University of Toronto Mississauga, Canada

*Correspondence: Bin Wan binwan@nigpas.ac.cn

Specialty section: This article was submitted to Paleontology, a section of the journal Frontiers in Earth Science

Received: 26 September 2021 Accepted: 22 November 2021 Published: 08 December 2021

Citation:

Wang $X$, Wu M, Wan B, Niu C, Zheng W, Guan C, Pang K, Chen Z and Yuan $X$ (2021) Evolution of Holdfast Diversity and Attachment Strategies of

Ediacaran Benthic Macroalgae. Front. Earth Sci. 9:783427. doi: 10.3389/feart.2021.783427
Holdfast morphologies and attachment strategies of benthic macroalgae are somewhat flexible and controlled by both the substrate condition and species. Six forms (tapered base, globose holdfast, composite globose holdfast, discoidal holdfast, rhizoids and horizontal rhizomes) of attachment structures of Ediacaran benthic macroalgae are recognized from the early Ediacaran Lantian biota and late Ediacaran Miaohe biota in South China based on functional morphology. Each form is considered either adapted to firm substrates that dominate the Precambrian seafloor, or soft substrates that are more common in the Phanerozoic. The results show a diversification in both holdfast morphology and attachment strategies of macroalgae during the Ediacaran Period. In the early Ediacaran Lantian biota, none of the benthic macroalgae is adapted to soft substrates, while in the late Ediacaran Miaohe biota, a considerable number (41\%) of species are adapted to relatively soft substrates. This shift might be an adaptive response to the diversification of macroalgae and a changing substrate condition during the Ediacaran Period: the decline of microbial mats and increase of water content in the sediments in the Ediacaran.

Keywords: Ediacaran, macroalgae, holdfast, South China, substrate condition

\section{INTRODUCTION}

Benthic macroalgae are important components of modern and past ecosystems. They are more efficient primary producers than phytoplankton (Bunt, 1975) and provide food and habitats for many other organisms (e.g., Steneck et al., 2002).

The evolution of benthic macroalgae experienced a prolonged stasis since its first appearance (Du et al., 1986; Dong et al., 2008; Xiao, 2013) in the Mesoproterozoic to early Neoproterozoic, and a sudden expansion in morphospace in the Ediacaran (Xiao and Dong, 2006; Bykova et al., 2020). The cause of the increase in morphological disparity might be the drop of $p \mathrm{CO}_{2}$ in the atmosphere and seawater after the Cryogenian Snowball Earth glaciations (Xiao and Dong, 2006).

The morphology of the holdfast of benthic macroalgae also diversified with the expansion in morphospace. Holdfasts attach macroalgae to substrates, and their morphologies are greatly influenced by the property of substrates and reflect the attachment strategy adopted by the macroalgae. As a result, the morphology of holdfasts may serve as a proxy, to some extent, for 


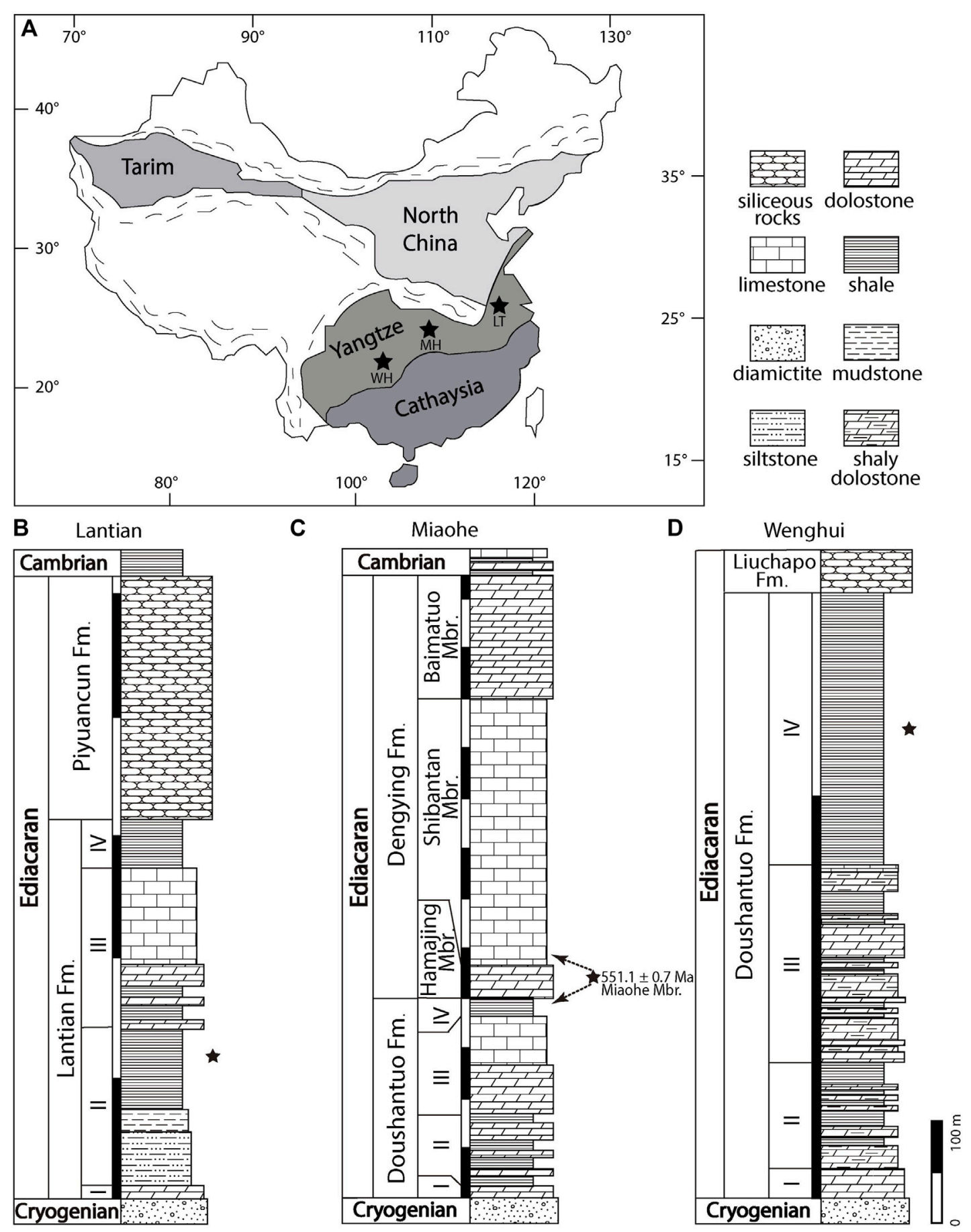

FIGURE 1 | Map and stratigraphic columns of the study areas. Modified from Wan et al. (2020) and Wang Y. et al. (2020). (A) Map showing fossil localities: Lantian (LT), Miaohe (MH), and Wenghui (WH). (B-D) Stratigraphic columns of Lantian, Miaohe, and Wenghui, respectively. Stars mark the fossil horizons in (B-D). Dashed arrows mark alternative correlations of the Miaohe Member. Fm. = Formation; Mbr. = Member.

the substrate conditions. For instance, Dornbos et al. (2005) and Lei et al. (2014) have investigated the evolution of attachment strategies of benthic metazoans as a response to the changing substrate conditions in the Cambrian.
The agronomic revolution (AR) or the Cambrian substrate revolution (CSR) is one of the greatest shifts in substrate conditions, transforming from Proterozoic-style substrates to Phanerozoic mixed layers. Typical Proterozoic-style substrates 
were firm and well-layered, with low water content and ubiquitous microbial mats; in contrast, typical Phanerozoicstyle soft substrates were soupy, water-rich mixed layers (Bottjer et al., 2000). The AR was driven by increasing bioturbation that incorporated water into the sediment (Kloss et al., 2015), but its exact timing and extent have not been yet clearly defined. In the early Cambrian, the AR has already had an effect (Dornbos et al., 2005), and had almost been finished in the late Cambrian (Bottjer et al., 2000). Considering the relatively diverse and abundant trace fossils in the late Neoproterozoic (e.g., Chen et al., 2018; Chen et al., 2019; Xiao et al., 2019), the AR is supposed to have a root back in the Precambrian, but the scarcity of Precambrian biotas restrained the insight to the evolution of substrate conditions during this period. Recently, a large number of specimens of fossil macroalgae with holdfasts preserved intact yielded from the Lantian biota (Yuan and Cao, 1999; Yuan et al., 2011; Bin et al., 2013) and the Miaohe biota (Xiao et al., 2002; Ye et al., 2019a) offered a chance to examine the evolution of substrate conditions in the Ediacaran.

This study focuses on the evolution of macroalgal holdfasts, attachment strategies and substrate conditions during the Ediacaran Period by examining Lagerstätten in South China: the early Ediacaran Lantian biota and the late Ediacaran Miaohe biota. Both biotas are preserved in black shales, and they also share comparable geological settings and depositional environments. We described holdfast morphologies of benthic macroalgae and analyzed their attachment strategies to understand the dynamic of substrate conditions in the early and late Ediacaran.

\section{GEOLOGICAL SETTING}

The Lantian biota is preserved in the Member II black shale of the Ediacaran Lantian Formation in the Anhui province (Figures 1A,B). Underlain by the Cryogenian Leigongwu diamictite and topped by the latest Ediacaran Piyuancun Formation, the Lantian Formation holds the fossil record of life between the end of the Snowball Earth to the eve of the Cambrian Explosion. It consists of four lithological members at the Lantian section (Figure 1B), i.e., in ascending order, Members I-IV. The lowest Member I is the cap carbonate ( $4 \mathrm{~m}$ thick); the Member II consists of siltstone (23 $\mathrm{m}$ thick), mudstone ( $8.6 \mathrm{~m}$ thick) and fossiliferous black shale (34 $\mathrm{m}$ thick); the Member III consists of dolomite interbedded with black shale ( $26 \mathrm{~m}$ thick) and limestone ( $40 \mathrm{~m}$ thick); the uppermost Member IV consists of black mudstone, $20 \mathrm{~m}$ in thickness (Guan et al., 2014; Wan et al., 2014; Wan et al., 2016). The Lantian Formation is the lithostratigraphic equivalent to the Doushantuo Formation in the Hubei Province (Yuan et al., 2011), which has been constrained to be between $635 \mathrm{Ma}$ to $551 \mathrm{Ma}$ (Condon et al., 2005), and therefore the age of the Lantian biota is considered between 635 and $590 \mathrm{Ma}$ (Yuan et al., 2011; Wan et al., 2016).

The sedimentary environment of the Lantian Formation was a restricted shelf basin (Zhu et al., 2007) at low to middle paleolatitudes (Li et al., 2008; Zhang et al., 2015). The in situ preserved benthic macroalgae and fine parallel laminations suggest that the deposition probably took place in a quiet environment below the storm wave base but within the photic zone (Yuan et al., 2011). Nevertheless, occasionally alignments of fossils in parallel and/or perpendicular directions indicate relatively weak current or wave movements.

The Miaohe biota refers to the fossil assemblage preserved in a siliceous black shale unit known as the Miaohe Member of the Ediacaran Doushantuo Formation (Figures 1C,D) which crops out in the Hubei and Guizhou provinces. Traditionally, the Miaohe Member is considered the equivalent of the uppermost black shale member of the Ediacaran Doushantuo Formation (Jiang et al., 2011; Xiao et al., 2017; Zhou et al., 2017). The Doushantuo Formation, as mentioned above, is a lithostratigraphic equivalent of the Lantian Formation. In the Miaohe area of the Hubei province and Wenghui area of the Guizhou province, the Doushantuo Formation overlain the Cryogenian Nantuo Formation and is overlaid by the latest Ediacaran Dengying and Liuchapo formations respectively. The Doushantuo Formation is $255 \mathrm{~m}$ thick at Miaohe and $79 \mathrm{~m}$ thick at Wenghui. Within the Doushantuo Formation, four members are discerned, in ascending order: a cap carbonate unit at the bottom (Member I, $5 \mathrm{~m}$ thick at Miaohe and $7 \mathrm{~m}$ thick at Wenghui), black shale interbedded with dolomite (Member II, $150 \mathrm{~m}$ thick at Miaohe and $10 \mathrm{~m}$ thick at Wenghui), laminated dolomite (Member III, $80 \mathrm{~m}$ thick at Miaohe and $17 \mathrm{~m}$ thick at Wenghui), and black shale and organic-rich mudstone at the top (Member IV, $20 \mathrm{~m}$ thick at Miaohe and $45 \mathrm{~m}$ thick at Wenghui). Nevertheless, An et al. (2015) proposed an alternative correlation that regards the Miaohe Member as an equivalent of the lower Shibantan Member of the Dengying Formation. The Miaohe Member yields diverse macroscopic fossils in the Miaohe area and several other localities in Hubei (Xiao et al., 2002; An et al., 2015; Ye et al., 2019a), and also in the Wenghui area in Guizhou (Zhao et al., 2004; Wang et al., 2014; Wang et al., 2016). Its age is constrained to $551 \mathrm{Ma}$ (TIMS U-Pb dating, Condon et al., 2005). This black shale member is interpreted as transgressive sediments deposited during sea-level rise (Jiang et al., 2007; Jiang et al., 2011), which may represent a restricted intra-shelf basin setting in the Yangtze Gorges area (Zhu et al., 2013) at low paleolatitudes (Li et al., 2008), and probably represent a continental slope environment in the Wenghui area (Jiang et al., 2011). The surface sediment of the Wenghui area was considered to be soupy (Wang and Wang, 2008).

\section{MATERIAL AND METHODS}

Specimens from the Lantian and Miaohe biotas are deposited in the Nanjing Institute of Geology and Palaeontology, except for the Gesinella and Globusphyton specimens which are deposited in Guizhou University.

In order to determine attachment strategies of benthic macroalgae in the Lantian and Miaohe biotas, a detailed examination of macroalgal holdfasts was conducted. Observations and measurements were carried out directly on fossil specimens or pictures of fossils from these biotas. Based on 


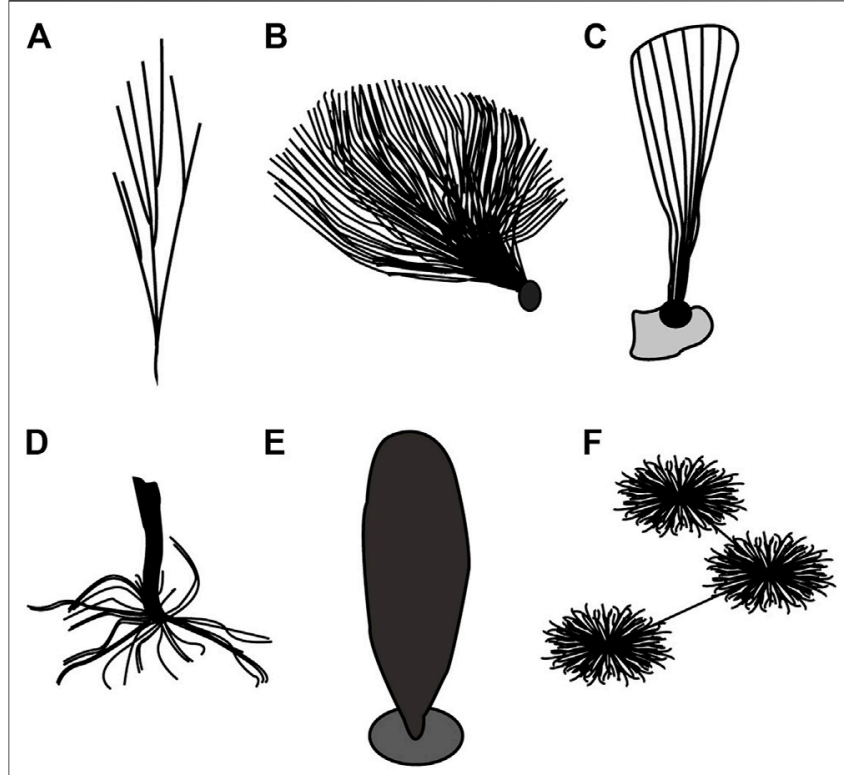

FIGURE 2 | Schematic illustration of Holdfast morphologies of benthic macroalgae from the Lantian and Miaohe biotas. (A) Tapered base of branching alga Doushantuophyton. (B) Globose holdfast of bush-like alga Anhuiphyton. (C) Composite globose with diffused organic mass of fanlike alga Flabellophyton. (D) Rhizoids of rod-like alga Baculiphyca. (E) Discoidal holdfast of rod-like alga Gesinella. (F) Horizontal rhizome of bush-like alga Globusphyton.

functional morphology, the holdfasts were classified into forms that were either adapted to firm and coherent substrates which dominated the Precambrian seafloor, or soft and soupy substrates that are more common in the Phanerozoic.

As a part of interpreting the adaptive morphology of globular holdfasts, a bivariate Spearman rank-order correlation (Spearman, 1904) was performed to determine if there is a correlation between the size of the thallus and the holdfast of Flabellophyton, which is the most representative and abundant taxon in the Lantian biota. A relatively small holdfast compared to the thallus may reflect minimal or no bioturbation (Loduca et al., 2017), hence the correlation (or lack thereof) would indicate if substrate conditions were relevant to the survival of benthic macroalgae or not. We focused on holdfasts instead of the amorphous organic mass here, because the organic mass may represent adhesive polypeptides (e.g., Levi and Friedlander, 2004) exuded from the holdfast rather than an anamical structure. Two variables used here are the thallus area and the cross-section area of the globular holdfast. The thallus of Flabellophyton was an inverted hollow cone originally, and its fan-like fossil represents a projection of a cone on a two-dimensional surface (Wan et al., 2020). The projection is also equal to the frontal area facing into the flow direction, making it an important parameter for benthic macroalgae to withstand moving water. The cross-section area of the globular holdfast is calculated from the diameter which could be directly measured.

Fossil specimens were photographed under a Nikon DSLR D850, a Zeiss stereo microscope Axio Zoom V16. Measurements were made from photos of specimens using ImageJ, version $1.52 \mathrm{a}$
(Rasband, 2018). Statistical analysis was carried out by using SPSS, version 23 (IBM Corp, 2015).

\section{RESULTS AND DISCUSSION}

\section{Functional Morphology of Holdfasts in the Early Ediacaran Lantian Biota \\ Tapered Base}

The base of the macroalgae tapers downwards to a point (Figure 2A; Figures 3A,B), with no differentiated holdfast. This could be an adaption for shallow insertion into sediments, similar to the strategy adopted by benthic invertebrates referred to shallow sediment stickers (Seilacher, 1999). The tapered base is an uncommon style of attachment for Lantian algae, which only have been found in simple dichotomously branching macroalgae, such as Doushantuophyton and Enteromorphites. Fragile structures such as rhizoidal holdfasts can be lost in some fossil specimens (Ye et al., 2019a). However, we have not found any other structures attach to the taper base in all specimens.

The tapered base can be generally regarded as an analogue to the bare rhizome holdfast (Wang Y. et al., 2020) from the Miaohe biota in the Wenghui area, but the latter may be associated with filamentous rhizoids which have never been found in the tapered base. The possible alga Protoconites from the Miaohe biota also bears a tapered base. Protoconites is fanlike compression with a tapered basal end, lacking obvious means of attachment. The interpretation of the affinity of Protoconites varies from scyphozoan to eukaryotic alga (Xiao et al., 2002). Comparable functional morphology has also been found in Cambrian suspension feeders, such as shallow sediment sticking demosponge Takakkawia (Dornbos et al., 2005) and helicoplacoid echinoderms (Dornbos and Bottjer, 2000).

A tapered morphology shows that their entire body mass was centered over a single point, which suggests that the substrates were not a water-rich mixed layer as we expect to find in typical Phanerozoic-style substrates, because these organisms might easily sink into the soupy sediment and die. Hence, shallow sediment stickers and algae that possess tapered bases are considered adapted to Proterozoic-style substrates, which were firm and well-layered and had low water content and ubiquitous microbial mats.

\section{Globose Holdfast}

A globose holdfast is globular to subglobular and buried shallow in the sediment (Figure 2B; Figures 3C,D). Globose holdfasts are found in bush-like algae, including Anhuiphyton, Huangshanphyton, and Marpolia from the Lantian biota. Occasionally, at the bottom of the globose holdfast, a tiny cone protrudes downwards. Comparable forms have also been found in the Miaohe biota in the Wenghui area and categorized into canopy rhizome holdfast (Wang Y. et al., 2020).

The globose holdfast in Ediacaran macroalgae would not be an effective anchoring structure on Phanerozoic mixed layers, because a sphere is not the optimal shape to resist upward 

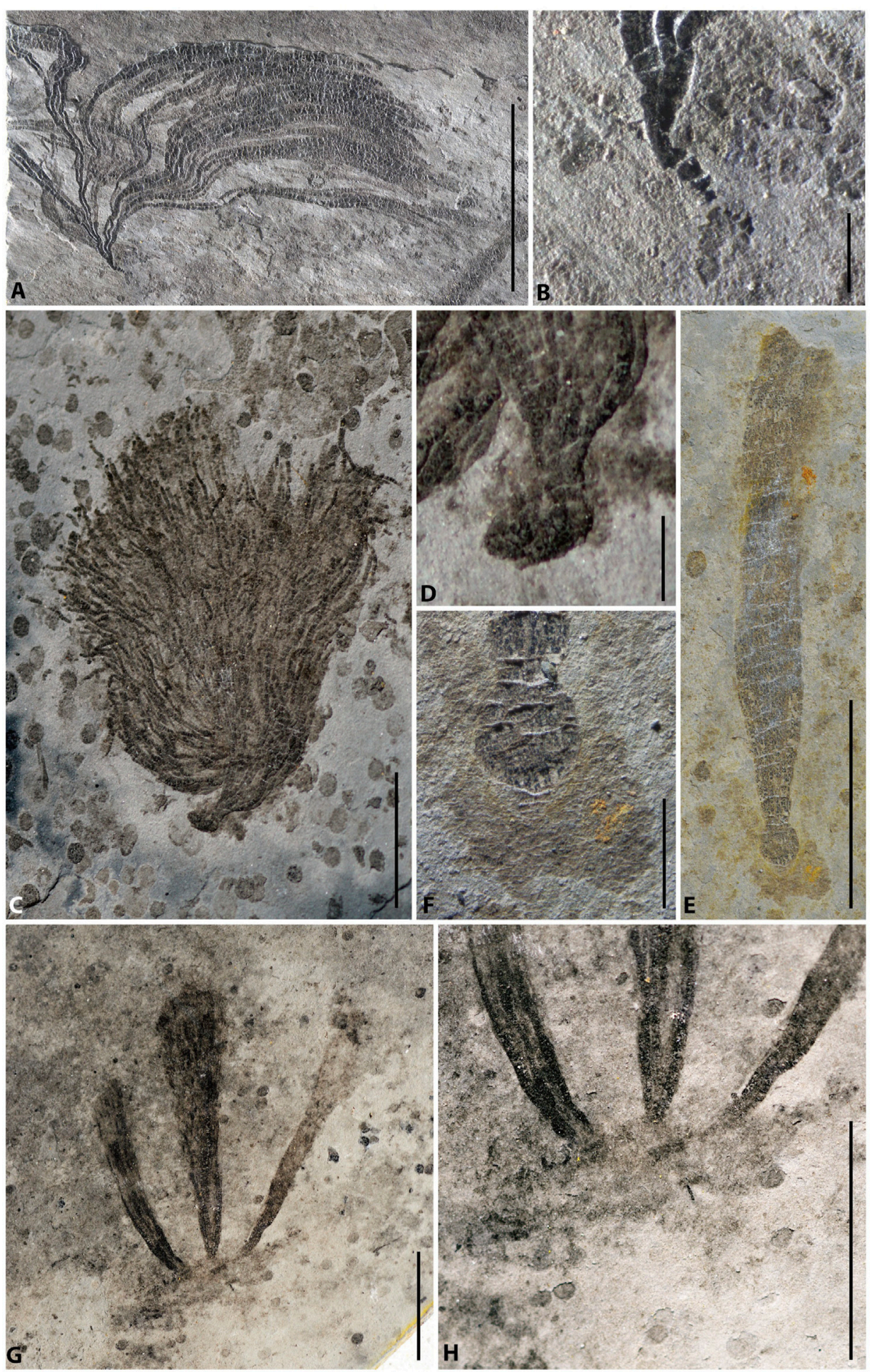

FIGURE 3 | Macroalgae and their holdfasts from the Lantian biota. (A) Doushantuophyton cometa, PB23767. (B) Enlargement of the holdfast in (A) showing a simple tapered morphology. (C) Anhuiphyton lineatum, PB23769. (D) Enlargement of the globular holdfast in (C). (E) Flabellophyton lantianense, PB23768. (F) Enlargement of the globular holdfast in (E), with amorphous organic mass. (G) Three Flabellophyton thalli rise from a common organic mass, PB23770. (H) Enlargement of the holdfast in (G). Scale bars represent $10 \mathrm{~mm}(\mathbf{A}, \mathbf{C}, \mathbf{E}, \mathbf{G})$ and $1 \mathrm{~mm}(\mathbf{B}, \mathbf{D}, \mathbf{F}, \mathbf{H})$. 


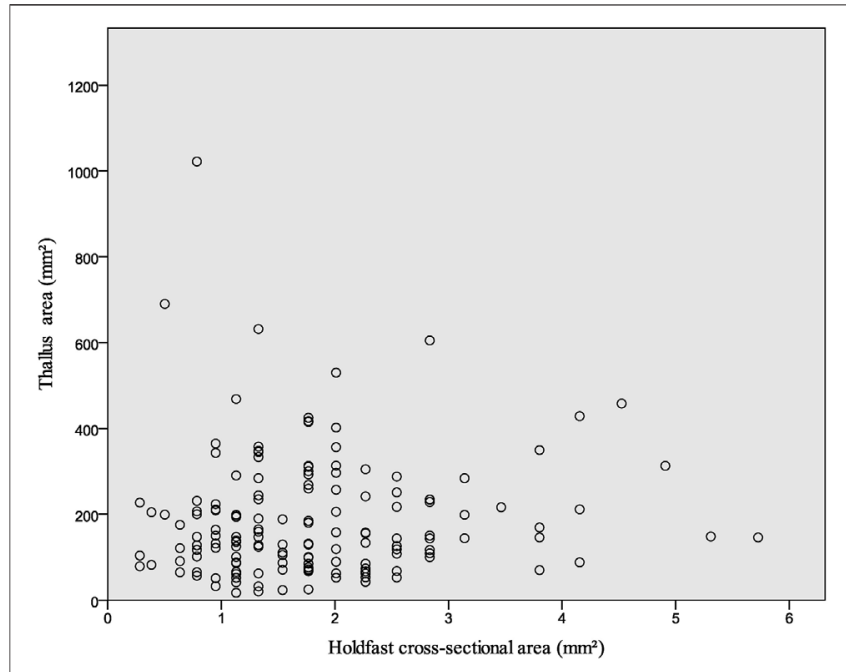

FIGURE 4 | Thallus area vs. holdfast cross-sectional area for macroalga Flabellophyton from the Lantian biota. $N=154$.

movements. As an uprooting experiment showed (Mickovski and Ennos, 2003), among the common shapes of holdfasts, it was the second easiest to uproot. The force required to uproot the globose holdfast model was very close to the shape of an inverted conical model, which was the easiest shape to uproot. Interestingly, inverted conical is also the shape of attachment structures of the benthic organisms referred to as shallow sediment stickers discussed above.

From the perspective of the holdfast, all the factors that affect attachment [i.e., shape, depth of embedment, the size of the holdfast (Mickovski and Ennos, 2003)] are hardly favorable for effective attachment of a globose holdfast. As a result, the property of the substrate seems to be decisive for the success of globose holdfasts. The substrates had to be relatively firm to provide enough support for the globose holdfast to resist uprooting or sinking, but not completely sealed by microbial mats and had to have ample water content to allow the globose to penetrate the top several millimeters of the substrates. Hence, we consider globular holdfasts are adaptive to less typical Proterozoic-style substrates, potentially represents the transition to soupy substrates.

\section{Composite Globose Holdfast}

In some conical algae, especially in well preserved Flabellophyton specimens, an amorphous organic mass may be found surrounding the globose holdfast (Figure 2C). We categorized it into composite globose holdfast, as a variation of the simple globose holdfast discussed above. The mass is usually thinner and has a fainter appearance than the holdfast itself (Figures 3E,F); it probably represents adhesive polypeptides (e.g., Levi and Friedlander, 2004) exuded from the holdfast for agglutinating sediment particles. In other cases, the globose holdfast may attach to a platy carbonaceous structure at its bottom. Moreover, multiple thalli may arise from a common organic mass (Figures 3G,H) reminiscent of some individual Longfengshania specimens which can be merged into a common, irregular carbonaceous mass as well (Hofmann, 1985). Both the amorphous mass and platy structure potentially provide additional anchorage strength for the alga.

Most of the Flabellophyton specimens were uprooted from the substrates before being buried, due to the relatively weak current or wave movements. As a result, their holdfasts are preserved as spheres without surrounding amorphous mass. The size of the holdfast is not correlated with the size of the conical thallus, as depicted in Figure 4. Small globose holdfasts are found in both large and small specimens. The correlation analysis also shows there is no statistically significant correlation between the cross-section area of the holdfast and the area of the thallus for Flabellophyton, $r_{s}(154)=0.091, p=0.262$. In contrast, there is a positive correlation between the wet weight/ surface area of the above-sediment part and holdfast volume in modern algae (Anderson et al., 2006; Bedinger et al., 2013), possibly due to larger size, which experiences more dragging and have greater attachment strength (e.g., Denny et al., 1985; Wernberg and Thomsen, 2005).

\section{Functional Morphology of Holdfasts in the Late Ediacaran Miaohe Biota \\ Rhizoid}

Rhizoid holdfasts are the most common type in the Miaohe biota, exhibiting root-like filaments diverging from the base of thallus (Figure 2D). Rhizoid holdfasts are well-developed in algae such as Longifuniculum (Figure 5A), Baculiphyca (Figures 5C,D), Konglingiphyton (Figure 5F), and Gesinella (Figure 5E).

Rhizoids are sophisticated structures that increase the surface area of the anchoring device and are common in modern algae living on soft substrate. A larger surface area provides more frictional force between sediment grains and rhizoids (e.g., Yang et al., 2021) to stabilize the alga in soft sediments. Rhizoids also have the ability to bind grains to form clusters. The weight of grains adhered by rhizoids contributes to the anchorage of the alga as well, however, we did not observe any grains coarser than ambient sediments in studied specimens. Similar to rhizoids in morphology, a root-like holdfast is suggested to be an adaptation of benthic metazoans that developed to live on soft mud, and are common in fossil crinoids (Sprinkle and Guensburg, 1995). Root-like holdfasts are considered to be one of the indicators for typical Phanerozoicstyle life mode for benthic metazoans (Dornbos et al., 2005) that lived on soupy mixed layers. As this conclusion is based on merely functional morphology, the interaction between the substrate property and holdfast morphology, it is also applicable to organisms with comparable morphology besides benthic metazoans, such as algae.

\section{Discoidal Holdfast}

Discoidal holdfasts are common in the Miaohe biota, displaying a disc-like structure, attached to the base of the thallus (Figure 2E, Figure 5B). Globose structures may be compressed to become discs that resemble discoidal holdfasts. However, discoidal holdfasts are more flattened and often have an elliptical appearance with a stem attached to the center. Discoidal holdfasts also do not exhibit thickened edges as flattened spheres do. Simple basal discs found in the early 

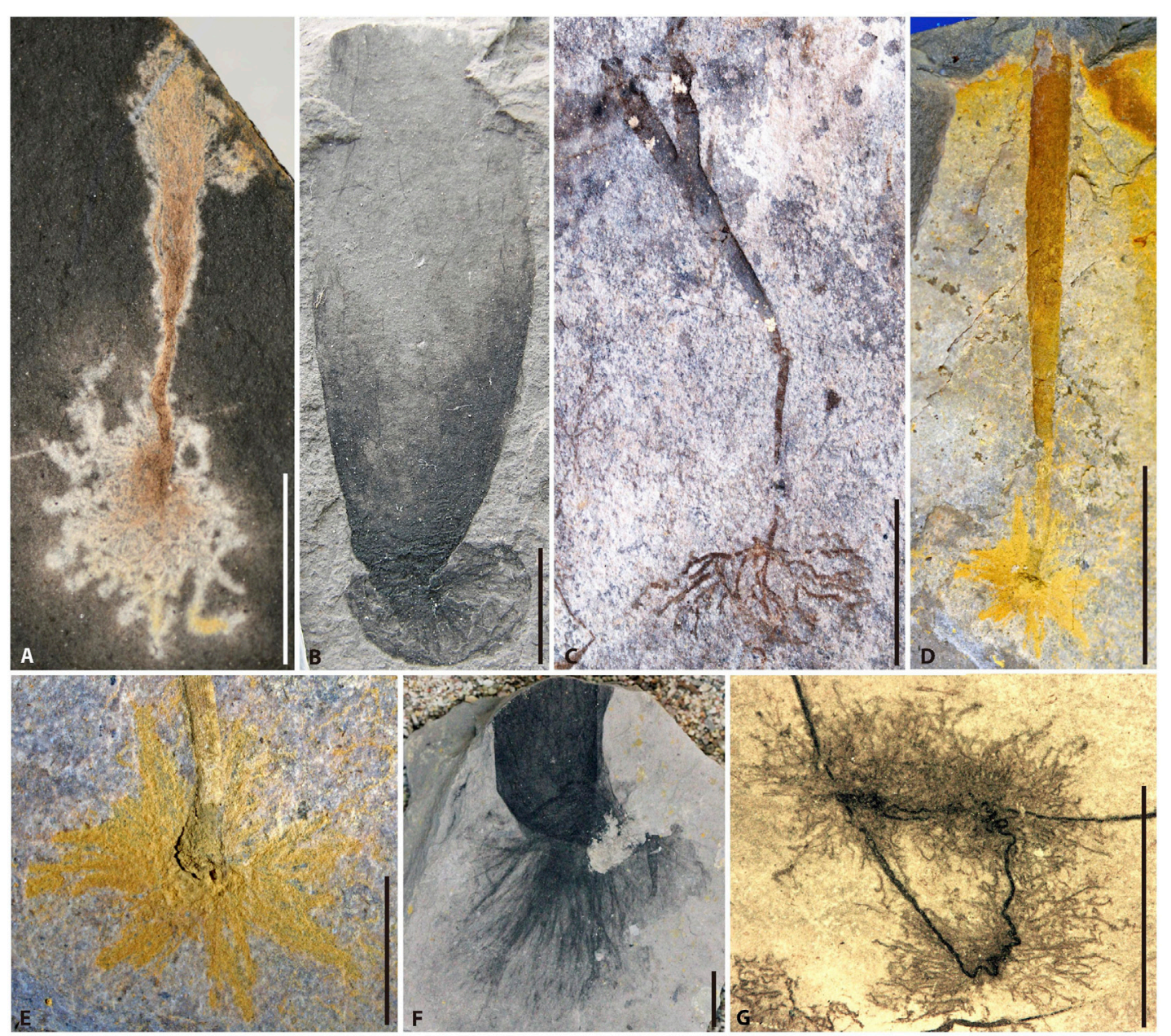

FIGURE 5|Macroalgae and their holdfasts from the Miaohe biota. (A) Longifuniculum dissolutum with a rhizoidal holdfast, PB23771. (B) Gesinella hunanensis with a discodial holdfast, MH-40-245B. (C) Konglingiphyton erecta, PB23773. (D) Baculiphyca taeniata, PB23772. (E) Enlargement of the rhizoidal holdfast in (D). (F) Gesinella hunanensis with rhizoids, MH-57-1058B. (G) Globusphyton lineare with horizontal rhizomes, MH-40-0248. Scale bars represent 10 mm.

Neoproterozoic macroalgae Longfengshania and Protoarenicola may represent some of the earliest holdfasts (Du et al., 1986; Dong et al., 2008). In typical Ediacara-type fossil Lagerstätten, disc-like holdfasts are prevalent, for instance, in Ediacaran fronds Arborea (Hofmann et al., 2008; Wang X. et al., 2020) and Primocandelabrum (Kenchington and Wilby, 2017). Seilacher (1999) suggested that these Ediacara-type organisms were attached on the surface of the seafloor, which was relatively firm due to the presence of microbial mats. Any immobile benthic metazoans that simply lived by attaching to unconsolidated substrates, were well adapted to Proterozoicstyle substrates (Dornbos et al., 2005). Considering the resemblance of discoidal holdfasts between macroalgae and other Ediacaran benthic organisms, they probably served as basal attachments in the same manner. As a result, the discoidal holdfast was the adaptation for both macroalgae and Ediacara-type organisms to Proterozoic-style firm substrates.

\section{Horizontal Rhizome}

The horizontal rhizome (Figure 2F) is another anchorage structure found in the Miaohe biota. Several pompom-like individuals of Globusphyton are interconnected by horizontal rhizomes which may creep on the seafloor or were shallowly buried within the sediment (Figure 5G). In terms of anchorage capacity, horizontal rhizomes join numerous individuals together, forming a network that provides more effective attachment than a solitary individual could achieve.

Wang Y. et al. (2020) proposed a classification of macroalgal holdfasts in the late Ediacaran Miaohe biota in the Wenghui area. Among the four major types recognized by them, bare and canopy rhizomes resemble tapered and globular holdfasts in the early Ediacaran Lantian biota, whereas pithy and differentiated rhizomes can be roughly correlated to the aforementioned filamentous rhizoids and horizontal rhizomes, respectively. 


\section{The Evolution of Holdfast Diversity}

Holdfasts of macroalgae that predate the Ediacaran Period were simple and small, the prevalent holdfast type at that period was disc-like. In the Mesoproterozoic, discoidal structures attached to rod-like macroalgae Tawuia may represent the first unequivocal holdfast (Kumar, 2001; Xiao and Dong, 2006). Such type of holdfast was also ubiquitous in the Tonian (Dong, et al., 2008; Li et al., 2020) and persisted to the Ediacaran. The simple and invariable holdfast morphology at that time reflects the low diversity of macroalgae and the microbial mat ecosystem was dominant before the Ediacaran. The small discoidal holdfast provided sufficient anchorage to attach on the microbial mat.

During the Ediacaran, holdfasts of macroalgae remarkably diversified, at least six functional morphotypes were recognized. This morphological diversification of macroalgal holdfasts was probably triggered by ocean oxygenation and macroalgae radiation in the Ediacaran Period. The deep sea became intermittently oxic at the beginning of the Ediacaran (Sahoo et al., 2012; Wang et al., 2017; Xiao and Narbonne, 2020). The microbial mat ecosystem declined, and a new ecosystem dominated by erect benthic macroalgae and animals started to establish (Liu et al., 2015; Wan et al., 2020). For example, the benthic macroalga Flabellophyton is a common member of the Lantian, Shibantan, and typical Ediacara biotas distributed in both China and Australia (Wan et al., 2020; Xiao et al., 2020). Through the Ediacaran, the holdfast of Flabellophyton typicum found in both China and Australia (Xiao et al., 2020; Wan et al., 2020) maintained a composite globose shape and was invariable to the significant change of size of the thallus. The morphological stability suggests that the holdfast morphology was at least partially species-specific. As a result, the drastic increase of macroalgae diversity (Ye, 2019b; Bykova et al., 2020) may have also contributed to the diversification of holdfasts during this period.

\section{Attachment Strategy Innovations for Changing Substrate Condition}

One of the major factors that determine the attachment strategy of benthic macroscopic algae is the substrate condition (Verbruggen, 2008). The representative case is the comparison between Flabellophyton lantianense (Figures 3E,F) from the Lantian biota and Baculiphyca taeniata (Figures 5D,E) from the Miaohe biota, both of them possess thalli that are very similar in shape and size. The only conspicuous difference between these two species is the morphology of the holdfast: $B$. taeniata possesses rhizoids whereas $F$. lantianense does not. The almost identical above-sediment part and comparable paleoenvironments indicate that the occurrence of rhizoids is a response to changed substrate conditions. Benthic macroalgae have already occurred in the Mesoproterozoic, however, the rhizoids have not been found in any fossil macroalgae that predates late Ediacaran (Ye, 2019b). The absence of rhizoids in such a vast time interval probably indicates the predominance of Proterozoic-style firm substrates in this period. Therefore, the lack of rhizoids in the Lantian macroalgae indicates that they were not necessary for effective attachment at that time because the

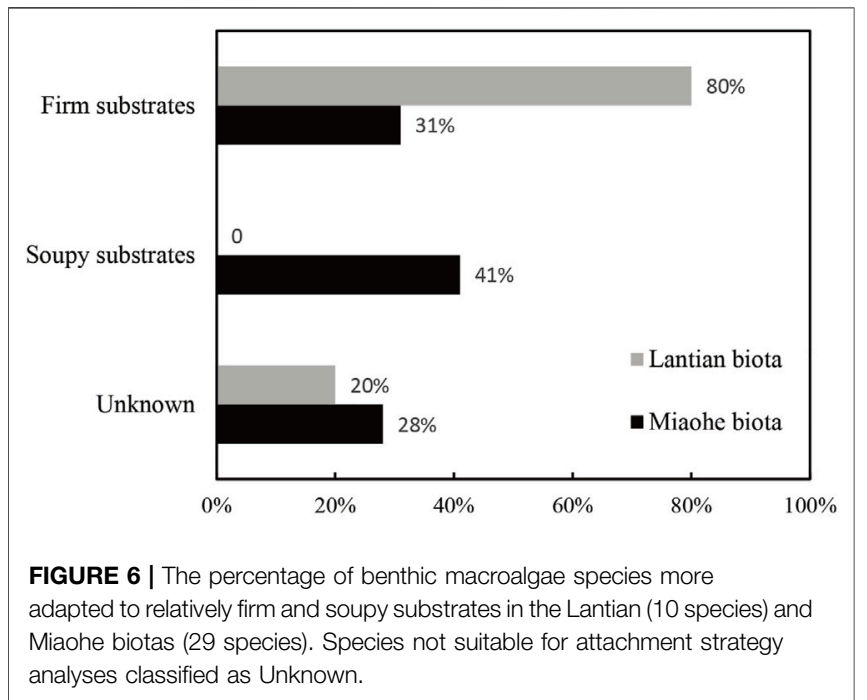

substrates were firm. The ubiquitous rhizoids in the younger late Ediacaran Miaohe biota may represent an adaptation to the changing substrate condition: from Proterozoic-style towards Phanerozoic-style substrates.

In order to determine whether the benthic macroalgae from the early Ediacaran Lantian biota to late Ediacaran Miaohe biota were adapted to the firm or soupy substrates, the morphology of their holdfasts was scrutinized in terms of functional adaptation. These holdfasts were categorized into six general forms which have implications for substrate conditions. As discussed above, tapered base, globose, composite globose, and discoidal forms were interpreted as adaptations to relatively firm substrates which were dominant most of the time of the Precambrian; filamentous rhizoids and horizontal rhizomes are considered to be adaptations to substrates with higher water content comparing to typical Proterozoic-style substrates.

The results show that, in the early Ediacaran Lantian biota, $80 \%$ of the benthic macroalga species (10 species in total) are adapted to firm substrates (Figure 6; Supplementary Material S1). The remaining $20 \%$ were incompletely preserved and their attachment strategies could not be determined, and were hence classified as unknown. The great majority of firm substrate dwellers suggests that the Lantian biota lived on firm Proterozoic-style substrates. In the late Ediacaran Miaohe biota, $31 \%$ of the benthic macroalga species (29 species in total) are adapted to firm substrates (Figure 6; Supplementary Material S1), $41 \%$ are adapted to soupy substrates, and $28 \%$ are unrecognizable, suggesting the substrates that the Miaohe biota lived on were soupy. Considering the similar depositional environments, the rise of soupy substrate adaptors in the Miaohe biota may indicate the onset of the transformation from firm substrates to soupy substrates had taken place between the age of the Lantian and Miaohe biotas.

During the great transition from the microbial mat to benthic macroscopic ecosystems in the Ediacaran-Cambrian periods (Butterfield, 2007; Wan et al., 2020; Xiao and Narbonne, 2020), the substrate condition also dramatically 


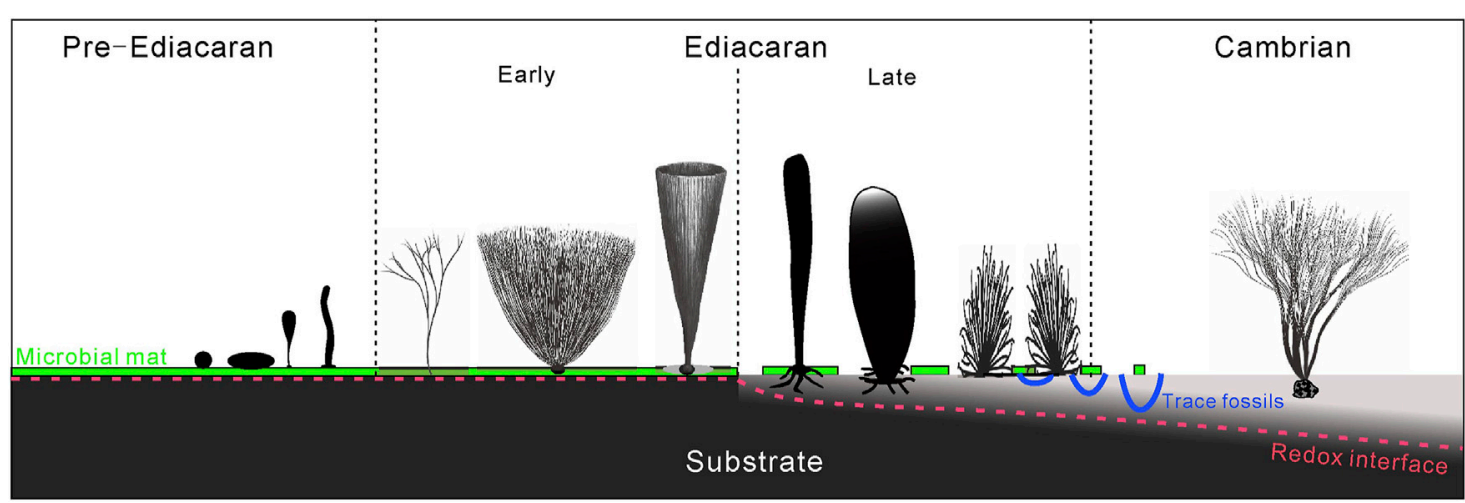

FIGURE 7 | Schematic illustration of macroalgal holdfast morphology and attachment strategy responding to a changing substrate condition.

transformed from the firm, microbial sealed sediments to the soft, water-rich sediments. Moreover, the redox interface migrated downwards to a deeper depth (Figure 7). Although benthic macroalgae (represented by the ChuariaTawuia assemblage) are not rare in pre-Ediacaran strata, the fossil record of erect benthic macroalgae, such as Longfengshania and Protoarenicola/Pararenicola (Tang et al., 2021) remains scarce. Macroalgae in the early Ediacaran, despite various shapes of the thalli, e.g., simple dichotomously branching, bush-like, or conical, were adapted to sticking on the surface of microbial mats while mats were still somewhat developed on the seafloor. Attachment innovations in macroalgae in the late Ediacaran, such as developed rhizoids and horizontal rhizomes, are typical adaptations for survival on unstable substrates with a higher water content compared to the early Ediacaran. It may represent adaptive responses to a changing substrate condition in the late Ediacaran, i.e., the decline of microbial mats and the increase of water content in the sediments. Holdfasts of macroalgae became more sophisticated in trapping grains to anchor on mixed substrates in the Cambrian. For example, Thamnophyton from the Cambrian Kaili biota show grains coarser than ambient sediments bound in its rhizoids (Yang et al., 2004; Zhao et al., 2011). In summary, the attachment strategy of benthic macroscopic algae became increasingly complex from Pre-Ediacaran to Cambrian, and exhibited some great innovations in the late Ediacaran, adapting to substrate condition and an ecosystem in transformation.

\section{CONCLUSION}

Adaptive morphological analysis indicates there are 6 holdfast forms (tapered base, globose holdfast, composite globose holdfast, discoidal holdfast, filamentous rhizoid, and horizontal rhizome) for benthic macroalgae from the early Ediacaran Lantian biota and late Ediacaran Miaohe biota in South China. The morphological variations between holdfasts may reflect various attachment strategies and further imply general conditions of substrates. In the Lantian biota, all the benthic macroalgae with attachment structures are adapted to firm substrates, while in the Miaohe biota, a significant number $(41 \%)$ of species are adapted to relatively soft substrates. The great diversification in holdfast morphology and attachment strategies which was marked by the appearance of complex rhizoidal holdfasts was a response to the diversification of macroalgae and changing substrate conditions during this period, i.e., the decline of microbial mat ecosystem and the founding of a benthic algae-dominated ecosystem. The results also provide evidence that the onset of the agronomic revolution (the Cambrian substrate revolution) likely predates the Cambrian and had a protracted effect on paleoecology and evolution onwards.

\section{DATA AVAILABILITY STATEMENT}

The original contributions presented in the study are included in the article/Supplementary Materials, further inquiries can be directed to the corresponding author.

\section{AUTHOR CONTRIBUTIONS}

BW and XW designed the research. XW, MW, WZ, BW, CN, KP, $\mathrm{ZC}$, and XY collected fossils. All authors contributed feedback on drafts, revised and approved the manuscript.

\section{FUNDING}

This research was supported by National Natural Science Foundation of China (41972005 and 41921002), Chinese Academy of Sciences (XDB26000000), National Key Research and Development Program of China (2017YFC0603101), State Key Laboratory of Palaeobiology and Stratigraphy (2102108 and 20201102), and the Youth Innovation Promotion Association of the CAS (grant 2021307). 


\section{ACKNOWLEDGMENTS}

We thank Chengxi $\mathrm{Wu}$ and Yarong Liu for assistance in fieldworks, and journal reviewers for their constructive feedback.

\section{REFERENCES}

An, Z., Jiang, G., Tong, J., Tian, L., Ye, Q., Song, H., et al. (2015). Stratigraphic Position of the Ediacaran Miaohe Biota and its Constrains on the Age of the Upper Doushantuo $\delta 13 \mathrm{C}$ Anomaly in the Yangtze Gorges Area, South China. Precambrian Res. 271, 243-253. doi:10.1016/ j.precamres.2015.10.007

Anderson, K., Close, L., Dewreede, R. E., Lynch, B. J., Ormond, C., and Walker, M. (2006). Biomechanical properties and holdfast morphology of coenocytic algae (Halimedales, Chlorophyta) in Bocas del Toro, Panama. J. Exp. Mar. Biol. Ecol. 328, 155-167. doi:10.1016/ j.jembe.2005.07.005

Bedinger, L. A., Bell, S. S., and Dawes, C. J. (2013). Rhizophytic Algal Communities of Shallow, Coastal Habitats in Florida: Components above and below the Sediment Surface. BMS 89, 437-460. doi:10.5343/ bms.2011.1151

Bin, W., Xunlai, Y., Zhe, C., Chengguo, G., Ke, P., Qing, T., et al. (2013). Quantitative Analysis of Flabellophyton from the Ediacaran Lantian Biota, South China: Application of Geometric Morphometrics in Precambrian Fossil Research. Acta Geol. Sin. 87, 905-915. doi:10.1111/17556724.12099

Bottjer, D. J., Hagadorn, J. W., and Dornbos, S. Q. (2000). The Cambrian Substrate Revolution. GSA Today 10, 1-7.

Bunt, J. S. (1975). "Primary Productivity of marine Ecosystems," in Primary Productivity of the Biosphere (New York: Springer), 169-183. doi:10.1007/ 978-3-642-80913-2_8

Butterfield, N. J. (2007). Macroevolution and Macroecology through Deep Time. Palaeontology 50, 41-55. doi:10.1111/j.1475-4983.2006.00613.x

Bykova, N., Loduca, S. T., Ye, Q., Marusin, V., Grazhdankin, D., and Xiao, S. (2020). Seaweeds through Time: Morphological and Ecological Analysis of Proterozoic and Early Paleozoic Benthic Macroalgae. Precambrian Res. 350, 105875. doi:10.1016/j.precamres.2020.105875

Chen, Z., Chen, X., Zhou, C., Yuan, X., and Xiao, S. (2018). Late Ediacaran Trackways Produced by Bilaterian Animals with Paired Appendages. Sci. Adv. 4, eaao6691. doi:10.1126/sciadv.aao6691

Chen, Z., Zhou, C., Yuan, X., and Xiao, S. (2019). Death March of a Segmented and Trilobate Bilaterian Elucidates Early Animal Evolution. Nature 573, 412-415. doi:10.1038/s41586-019-1522-7

Condon, D., Zhu, M., Bowring, S., Wang, W., Yang, A., and Jin, Y. (2005). U-pb Ages from the Neoproterozoic Doushantuo Formation, China. Science 308, 95-98. doi:10.1126/science.1107765

Denny, M. W., Daniel, T. L., and Koehl, M. A. R. (1985). Mechanical Limits to Size in Wave-Swept Organisms. Ecol. Monogr. 55, 69-102. doi:10.2307/1942526

Dong, L., Xiao, S., Shen, B., Yuan, X., Yan, X., and Peng, Y. (2008). Restudy of the Worm-like Carbonaceous Compression Fossils Protoarenicola, Pararenicola, and Sinosabellidites from Early Neoproterozoic Successions in North China. Palaeogeogr. Palaeoclimatol. Palaeoecol. 258, 138-161. doi:10.1016/j.palaeo.2007.05.019

Dornbos, S. Q., and Bottjer, D. J. (2000). Evolutionary Paleoecology of the Earliest Echinoderms: Helicoplacoids and the Cambrian Substrate Revolution. Geology 28, 839-842. doi:10.1130/0091-7613(2000) $028<0839$ :epotee $>2.3 . c 0 ; 2$

Dornbos, S. Q., Bottjer, D. J., and Chen, J.-Y. (2005). Paleoecology of Benthic Metazoans in the Early Cambrian Maotianshan Shale Biota and the Middle Cambrian Burgess Shale Biota: Evidence for the Cambrian Substrate Revolution. Palaeogeogr. Palaeoclimatol. Palaeoecol. 220, 47-67. doi:10.1016/ j.palaeo.2003.11.016

Du, R., Tian, L., and Li, H. (1986). Discovery of Megafossils in the Gaoyuzhuang Formation of the Changchengian System, Jixian. Acta Geol. Sin. 60, 115-120.

\section{SUPPLEMENTARY MATERIAL}

The Supplementary Material for this article can be found online at: https://www.frontiersin.org/articles/10.3389/feart.2021.783427/ full\#supplementary-material

Guan, C., Zhou, C., Wang, W., Wan, B., Yuan, X., and Chen, Z. (2014). Fluctuation of Shelf basin Redox Conditions in the Early Ediacaran: Evidence from Lantian Formation Black Shales in South China. Precambrian Res. 245, 1-12. doi:10.1016/j.precamres.2014.01.003

Hofmann, H. J., O’brien, S. J., and King, A. F. (2008). Ediacaran Biota on Bonavista Peninsula, Newfoundland, Canada. J. Paleontol. 82, 1-36. doi:10.1666/06-087.1

Hofmann, H. J., and Altken, J. D. (1979). Precambrian Biota from the Little Dal Group, Mackenzie Mountains, Northwestern Canada. Can. J. Earth Sci. 16, 150-166. doi:10.1139/e79-014

IBM Corp (2015). IBM SPSS Statistics for Windows. Version 23.0. Armonk, NY: IBM Corp.

Jiang, G., Kaufman, A. J., Christie-Blick, N., Zhang, S., and Wu, H. (2007). Carbon Isotope Variability across the Ediacaran Yangtze Platform in South China: Implications for a Large Surface-To-Deep Ocean $\delta 13 \mathrm{C}$ Gradient. Earth Planet. Sci. Lett. 261, 303-320. doi:10.1016/j.epsl.2007.07.009

Jiang, G., Shi, X., Zhang, S., Wang, Y., and Xiao, S. (2011). Stratigraphy and Paleogeography of the Ediacaran Doushantuo Formation (Ca. 635$551 \mathrm{Ma})$ in South China. Gondwana Res. 19, 831-849. doi:10.1016/ j.gr.2011.01.006

Kenchington, C. G., and Wilby, P. R. (2017). Rangeomorph Classification Schemes and Intra-specific Variation: Are All Characters Created Equal? Geol. Soc. Lond. Spec. Publ. 448, 221-250. doi:10.1144/sp448.19

Kloss, T. J., Dornbos, S. Q., and Chen, J. (2015). Substrate Adaptations of Sessile Benthic Metazoans during the Cambrian Radiation. Paleobiology 41, 342-352. doi:10.1017/pab.2014.22

Kumar, S. (2001). Mesoproterozoic Megafossil Chuaria-Tawuia Association May Represent Parts of a Multicellular Plant, Vindhyan Supergroup, Central India. Precambrian Res. 106, 187-211. doi:10.1016/s03019268(00)00093-0

Lei, Q.-P., Han, J., Ou, Q., and Wan, X.-Q. (2014). Sedentary Habits of Anthozoalike Animals in the Chengjiang Lagerstätte: Adaptive Strategies for Phanerozoic-Style Soft Substrates. Gondwana Res. 25, 966-974. doi:10.1016/ j.gr.2013.01.007

Levi, B., and Friedlander, M. (2004). Identification of Two Putative Adhesive Polypeptides in Caulerpa Prolifera Rhizoids Using an Adhesion Model System. J. Appl. Phycol. 16, 1-9. doi:10.1023/B: JAPH.0000019034.12015.87

Li, Z. X., Bogdanova, S. V., Collins, A. S., Davidson, A., De Waele, B., Ernst, R. E., et al. (2008). Assembly, Configuration, and Break-Up History of Rodinia: A Synthesis. Precambrian Res. 160, 179-210. doi:10.1016/ j.precamres.2007.04.021

Li, G., Chen, L., Pang, K., Zhou, G., Han, C., Yang, L., et al. (2020). An Assemblage of Macroscopic and Diversified Carbonaceous Compression Fossils from the Tonian Shiwangzhuang Formation in Western Shandong, North China. Precambrian Res. 346, 105801. doi:10.1016/j.precamres.2020.105801

Liu, A. G., Kenchington, C. G., and Mitchell, E. G. (2015). Remarkable Insights into the Paleoecology of the Avalonian Ediacaran Macrobiota. Gondwana Res. 27, 1355-1380. doi:10.1016/j.gr.2014.11.002

Loduca, S. T., Bykova, N., Wu, M., Xiao, S., and Zhao, Y. (2017). Seaweed Morphology and Ecology during the Great Animal Diversification Events of the Early Paleozoic: A Tale of Two Floras. Geobiology 15, 588-616. doi:10.1111/gbi.12244

Mickovski, S. B., and Ennos, A. R. (2003). Model and Whole-Plant Studies on the anchorage Capabilities of Bulbs. Plant Soil 255, 641-652. doi:10.1023/A: 1026007229517

Rasband, W. S. (2018). ImageJ. Bethesda, Maryland, USA: U. S. National Institutes of Health. Available at: https://imagej.nih.gov/ij/.

Sahoo, S. K., Planavsky, N. J., Kendall, B., Wang, X., Shi, X., Scott, C., et al. (2012). Ocean Oxygenation in the Wake of the Marinoan Glaciation. Nature 489, 546-549. doi:10.1038/nature11445 
Seilacher, A. (1999). Biomat-related Lifestyles in the Precambrian. Palaios 14, 86-93. doi:10.2307/3515363

Spearman, C. (1904). The Proof and Measurement of Association between Two Things. Am. J. Psychol. 15, 72-101. doi:10.2307/1412159

Sprinkle, J., and Guensburg, T. E. (1995). Origin of Echinoderms in the Paleozoic Evolutionary Fauna: The Role of Substrates. Palaios 10, 437-453. doi:10.2307/ 3515046

Steneck, R. S., Graham, M. H., Bourque, B. J., Corbett, D., Erlandson, J. M., Estes, J. A., et al. (2002). Kelp forest Ecosystems: Biodiversity, Stability, Resilience and Future. Envir. Conserv. 29, 436-459. doi:10.1017/S0376892902000322

Tang, Q., Pang, K., Li, G., Chen, L., Yuan, X., and Xiao, S. (2021). One-billion-yearold Epibionts Highlight Symbiotic Ecological Interactions in Early Eukaryote Evolution. Gondwana Res. 97, 22-33. doi:10.1016/j.gr.2021.05.008

Verbruggen, H. (2008). Resegmenting Halimeda. Molecular and Morphometric Studies of Species Boundaries within a green Algal Genus. Doctoral Dissertation. Ghent: Ghent University.

Wan, B., Xiao, S., Yuan, X., Chen, Z., Pang, K., Tang, Q., et al. (2014). Orbisiana Linearis from the Early Ediacaran Lantian Formation of South China and its Taphonomic and Ecological Implications. Precambrian Res. 255, 266-275. doi:10.1016/j.precamres.2014.09.028

Wan, B., Yuan, X., Chen, Z., Guan, C., Pang, K., Tang, Q., et al. (2016). Systematic Description of Putative Animal Fossils from the Early E Diacaran L Antian F Ormation of S Outh C Hina. Palaeontology 59, 515-532. doi:10.1111/pala.12242

Wan, B., Chen, Z., Yuan, X., Pang, K., Tang, Q., Guan, C., et al. (2020). A Tale of Three Taphonomic Modes: The Ediacaran Fossil Flabellophyton Preserved in limestone, Black Shale, and sandstone. Gondwana Res. 84, 296-314. doi:10.1016/j.gr.2020.04.003

Wang, Y., and Wang, X. (2008). Macroalgal Holdfasts and Their Interaction with Environments from the Neoproterozoic Doushantuo Formation in Guizhou, South China. Front. Biol. China 3, 113-122. doi:10.1007/s11515-008-0009-y

Wang, Y., Wang, Y., Du, W., and Wang, X. (2014). The Correlation between Macroscopic Algae and Metazoans in the Ediacaran: a Case Study on the Wenghui Biota in Northeastern Guizhou, South China. Aust. J. Earth Sci. 61, 967-977. doi:10.1080/08120099.2014.956231

Wang, Y., Wang, Y., Du, W., and Wang, X. (2016). New Data of Macrofossils in the Ediacaran Wenghui Biota from Guizhou, South China. Acta Geol. Sin. 90, 1611-1628. doi:10.1111/1755-6724.12805

Wang, W., Guan, C., Zhou, C., Peng, Y., Pratt, L. M., Chen, X., et al. (2017). Integrated Carbon, Sulfur, and Nitrogen Isotope Chemostratigraphy of the Ediacaran Lantian Formation in South China: Spatial Gradient, Ocean Redox Oscillation, and Fossil Distribution. Geobiology 15, 552-571. doi:10.1111/gbi.12226

Wang, X., Pang, K., Chen, Z., Wan, B., Xiao, S., Zhou, C., et al. (2020a). The Ediacaran Frondose Fossil Arborea from the Shibantan limestone of South China. J. Paleontol. 94, 1034-1050. doi:10.1017/jpa.2020.43

Wang, Y., Wang, Y., Tang, F., and Zhao, M. (2020b). Ediacaran Macroalgal Holdfasts and Their Evolution: a Case Study from China. Palaeontology 63, 821-840. doi:10.1111/pala.12485

Wernberg, T., and Thomsen, M. S. (2005). The Effect of Wave Exposure on the Morphology of Ecklonia Radiata. Aquat. Bot. 83, 61-70. doi:10.1016/ j.aquabot.2005.05.007

Xiao, S., and Dong, L. (2006). "On the Morphological and Ecological History of Proterozoic Macroalgae,” in Neoproterozoic Geobiology and Paleobiology. Editors S. Xiao and A. J. Kaufman (Netherlands: Springer), 57-90.

Xiao, S., Gehling, J. G., Evans, S. D., Hughes, I. V., and Droser, M. L. (2020). Probable Benthic Macroalgae from the Ediacara Member, South Australia. Precambrian Res. 350, 105903. doi:10.1016/j.precamres.2020.105903

Xiao, S. H., and Narbonne, G. M. (2020). “The Ediacaran Period,” in Geologic Time Scale 2020 (Amsterdam, Netherland: Elsevier), 521-561. doi:10.1016/ b978-0-12-824360-2.00018-8

Xiao, S., Yuan, X., Steiner, M., and Knoll, A. H. (2002). Macroscopic Carbonaceous Compressions in a Terminal Proterozoic Shale: A Systematic Reassessment of the Miaohe Biota, south China. J. Paleontol. 76, 3472-4376. doi:10.1017/ s0022336000041743

Xiao, S., Bykova, N., Kovalick, A., and Gill, B. C. (2017). Stable Carbon Isotopes of Sedimentary Kerogens and Carbonaceous Macrofossils from the Ediacaran Miaohe Member in South China: Implications for Stratigraphic Correlation and Sources of Sedimentary Organic Carbon. Precambrian Res. 302, 171-179. doi:10.1016/j.precamres.2017.10.006
Xiao, S., Chen, Z., Zhou, C., and Yuan, X. (2019). Surfing in and on Microbial Mats: Oxygen-Related Behavior of a Terminal Ediacaran Bilaterian Animal. Geology 47, 1054-1058. doi:10.1130/g46474.1

Xiao, S. (2013). "Written in Stone: the Fossil Record of Early Eukaryotes," in Evolution from the Galapagos: Two Centuries after Darwin. Editors G. Trueba and C. Montúfar (New York: Springer), 107-124. doi:10.1007/978-1-46146732-8_8

Xunlai, Y., Jun, L., and Ruiji, C. (1999). A Diverse Metaphyte Assemblage from the Neoproterozoic Black Shales of South China. Lethaia 32, 143-155. doi:10.1111/ j.1502-3931.1999.tb00533.x

Yang, R., Mao, J., Zhang, W., Jiang, L., and Gao, H. (2004). Bryophyte-like Fossil (Parafunaria Sinensis) from Early-Middle Cambrian Kaili Formation in Guizhou Province, China. Acta Bot. Sin. 46, 180-185. doi:10.3321/j.issn: 1672-9072.2004.02.009

Yang, Q., Zhang, C., Liu, P., and Jiang, J. (2021). The Role of Root Morphology and Pulling Direction in Pullout Resistance of Alfalfa Roots. Front. Plant Sci. 12, 580825. doi:10.3389/fpls.2021.580825

Ye, Q., Tong, J., An, Z., Hu, J., Tian, L., Guan, K., et al. (2019a). A Systematic Description of New Macrofossil Material from the Upper Ediacaran Miaohe Member in South China. J. Syst. Palaeontol. 17, 183-238. doi:10.1080/ 14772019.2017.1404499

Ye, Q. (2019b). Study on the Macroalgae in the Late Neoproterozoic of the Shennongjia and Huangling Area, South China. Doctoral Dissertation. Wuhan: China University of Geosciences.

Yuan, X., Chen, Z., Xiao, S., Zhou, C., and Hua, H. (2011). An Early Ediacaran Assemblage of Macroscopic and Morphologically Differentiated Eukaryotes. Nature 470, 390-393. doi:10.1038/nature09810

Zhang, S., Li, H., Jiang, G., Evans, D. A. D., Dong, J., Wu, H., et al. (2015). New Paleomagnetic Results from the Ediacaran Doushantuo Formation in South China and Their Paleogeographic Implications. Precambrian Res. 259, 130-142. doi:10.1016/j.precamres.2014.09.018

Zhao, Y., Chen, M. e., Peng, J., Yu, M., He, M., Wang, Y., et al. (2004). Discovery of a Miaohe-type Biota from the Neoproterozoic Doushantuo Formation in Jiangkou County, Guizhou Province, China. Chin.Sci.Bull. 49, 2224-2226. doi:10.1007/BF03185792

Zhao, Y., Zhu, M., Babcock, L., and Peng, J. (2011). The Kaili Biota: Marine Organisms from 508 Million Years Ago. Guiyang: Guizhou Science and Technology Press.

Zhou, C., Xiao, S., Wang, W., Guan, C., Ouyang, Q., and Chen, Z. (2017). The Stratigraphic Complexity of the Middle Ediacaran Carbon Isotopic Record in the Yangtze Gorges Area, South China, and its Implications for the Age and Chemostratigraphic Significance of the Shuram Excursion. Precambrian Res. 288, 23-38. doi:10.1016/j.precamres.2016.11.007

Zhu, M., Zhang, J., and Yang, A. (2007). Integrated Ediacaran (Sinian) Chronostratigraphy of South China. Palaeogeogr. Palaeoclimatol. Palaeoecol. 254, 7-61. doi:10.1016/j.palaeo.2007.03.025

Zhu, M., Lu, M., Zhang, J., Zhao, F., Li, G., Aihua, Y., et al. (2013). Carbon Isotope Chemostratigraphy and Sedimentary Facies Evolution of the Ediacaran Doushantuo Formation in Western Hubei, South China. Precambrian Res. 225, 7-28. doi:10.1016/j.precamres.2011.07.019

Conflict of Interest: The authors declare that the research was conducted in the absence of any commercial or financial relationships that could be construed as a potential conflict of interest.

Publisher's Note: All claims expressed in this article are solely those of the authors and do not necessarily represent those of their affiliated organizations, or those of the publisher, the editors and the reviewers. Any product that may be evaluated in this article, or claim that may be made by its manufacturer, is not guaranteed or endorsed by the publisher.

Copyright (c) 2021 Wang, Wu, Wan, Niu, Zheng, Guan, Pang, Chen and Yuan. This is an open-access article distributed under the terms of the Creative Commons Attribution License (CC BY). The use, distribution or reproduction in other forums is permitted, provided the original author(s) and the copyright owner(s) are credited and that the original publication in this journal is cited, in accordance with accepted academic practice. No use, distribution or reproduction is permitted which does not comply with these terms 